\title{
Specimens of Convolvulaceae linked to the plates of the Hortus Elthamensis
}

\author{
John R. I. Wood ${ }^{12}$, Serena K. Marner ${ }^{1}$, Robert W. Scotland ${ }^{1}$, Stephen A. Harris ${ }^{1}$ \\ 1 Department of Plant Sciences, University of Oxford, South Parks Road, Oxford, OX1 3RB, \\ U.K.
}

2 Honorary Research Associate, Royal Botanic Gardens, Kew, Richmond, Surrey, TW9 3AB, U.K.

Author for correspondence: jriwood@hotmail.com

\begin{abstract}
Dillenius's Hortus Elthamensis was published in 1732. In most versions the plates are uncoloured, but a few surviving coloured versions are known. The plates are of considerable historical and scientific importance as many Linnaean types are founded on these illustrations. The specimens on which the plates were based are still housed in the Oxford University Herbaria (OXF) and examples from Convolvulaceae are discussed to show how the plates were based on and sometimes copied exactly from the original specimens. A second step lectotypification is made for Ipomoea glaucifolia L. Our study of Convolvulaceae types implies that the corresponding specimens in other families should be consulted when interpreting ambiguous types based on plates in Hortus Elthamensis.
\end{abstract}

Keywords colour plates, Convolvulus, Dillenius, Ipomoea, lectotype, Oxford herbaria, typification.

\section{INTRODUCTION}

The German botanist Johann Jacob Dillenius (1684-1747) moved to England in 1721 following a lengthy correspondence with William Sherard (1659-1728), who had been impressed with Dillenius's earlier work on cryptograms. Dillenius settled in London where he was paid to arrange Sherard's personal herbarium. In the 1720s he made a major contribution to the third edition of Ray's Synopsis (1724) and throughout the decade worked on Sherard's Pinax project, an attempt to provide a complete synonymy of all then known plant names (Harris, 2015). When Sherard died, he left his herbarium and library to the University of Oxford and endowed a Professorship of Botany, stipulating that Dillenius be appointed as the first professor (Druce \& Vines 1907).

Dillenius did not move to Oxford until 1734, having been persuaded by William Sherard's brother, James (1666-1738) (Druce \& Vines 1907: xxiii), to write an account of the plants cultivated in his garden at Eltham (now part of Greater London). The result was the Hortus Elthamensis (1732) consisting of two folio volumes with 324 copper plates drawn and engraved by Dillenius and containing descriptions of 417 plants. Lists of the species in the Hortus are provided by Klinsmann (1856), Druce and Vines (1907) and by Schmidt (1965), although names may need updating. Most copies of the Hortus are uncoloured (Druce \& Vines 1907: 157), but the Oxford set is one of the very few coloured versions known to exist (another is at the Natural History Museum in London), the colouring having been done by Dillenius himself. 
The specimens on which the Hortus was based were originally distributed throughout the Sherardian herbarium at Oxford but were separated out by George Claridge Druce in the late nineteenth century (Druce \& Vines 1907: 157). Not all corresponding specimens were found and some that Druce selected appear not to have been used in the preparation of the plates (Clokie 1964: 89). Clokie unfortunately gives the impression that only in a few cases is there a direct link between the specimens to which Dillenius' label is attached and the plates. In the case of Convolvulaceae at least, this is not the case. In the examples discussed below, there can be little doubt that Dillenius used the specimen to prepare the corresponding plate although in some cases he may have only used elements of the specimen to complete the plate, as is, in fact, the practice of some botanical illustrators today.

Linnaeus visited Oxford in 1736 and met Dillenius, by then resident in Oxford as the Sherardian Professor of Botany (Jarvis 2007). The meeting went well and at the end Dillenius presented Linnaeus with a copy of Hortus Elthamensis. Linnaeus $(1753,1762)$ referred extensively to this work and almost all the plates are cited in the synonomy of Linnaean names. Today over a hundred serve as lectotypes of Linnaean names (Schmidt 1965, Jarvis 2007). Linnaeus' own copy of Hortus Elthamensis is at Jena (Schmidt 1965) and is uncoloured so he makes no reference to the distinct flower colour of species such as Ipomoea pandurata (L). Mey.

\section{THE PLATES AND THE SPECIMENS}

Inevitably as part of our monographic work on Convolvulus (Wood et al. 2015a) and Ipomoea (Wood et al. 2015b) we have come to evaluate these plates, most of which have been selected as lectotypes of different species, particularly in Ipomoea, including: Ipomoea obscura (L.) Ker Gawl. (as Convolvulus obscurus L., 'Convolvulus flore minore lacteo, fundo atrorubente' (Hort. Eltham. 1: 98, t. 83, f. 95) designated by Meeuse (1958: 746)); Ipomoea purpurea (L.) Roth (as Convolvulus purpureus L., 'Convolvulus folio cordato glabro, flore violaceo' (Hort. Eltham. 1: 100, t 84, f. 97) designated by Austin (1975: 193); Ipomoea cordatotriloba Dennst. (as Convolvulus carolinus L., 'Convolvulus folio hederaceo, arvensis flore dilute purpureo' (Hort. Eltham. 1: 100, t 84, f. 98) designated by Staples (Staples \& Jarvis 2006: 1020)); Ipomoea nil (L.) Roth (as Convolvulus nil, 'Convolvulus caeruleus, hederaceo folio, magis anguloso' (Hort. Eltham. 1: 96, t 80, f. 91), designated by Verdcourt (1957: 232)); and Ipomoea lacunosa L. (as 'Convolvulus stellatus, Periplocae rotundioris folio' (Hort. Eltham. 1: 103, t. 87, f. 103) designated by Staples (Staples \& Jarvis 2006: 1022). Five illustrations in Hortus Elthamensis were also selected by Shinners (1965) as lectotypes of unnamed Linnaean varieties of Convolvulus hederaceus L. (=Ipomoea nil (L.) Roth).

We have no issues with these lectotypifications, and it is true that "the plates and descriptions of the Hortus Elthamensis ... are so good that there is rarely need to consult the specimens typifying them" (Stearn 1957: 115). However, we have noticed that none of the authors designating lectotypes makes reference to the specimens from which the illustrations were drawn, nor to the coloured plates. It appears that they had not seen the corresponding specimens and were, perhaps, unaware they existed, even though their existence is plain from the publications of Druce \& Vines (1907), Stearn (1957), Clokie (1964) and Jarvis (2007: 20, 126). Thus Staples \& Jarvis (2006) comment in relation to Convolvulus carolinus (i.e. Ipomoea 
cordatotriloba)... 'the Dillenius specimen has apparently been lost', which is not the case. The specimen they selected as a topotype (Fig. 1A) is probably the specimen from which the plate was drawn (Fig. 1B). This is labelled in Dillenius' hand with the phrase name 'Convolvulus folio hederaceo, arvensis flore dilute purpureo', which corresponds to that of the plate, and a reference to 'H. Elth.'. Although the plate is not an exact copy of the specimen there are many elements in common and it is almost certain that the plate was based on this specimen.

Similarly, in their proposal to reject the name Ipomoea glaucifolia Staples et al. (2006: 535) discuss at length the difficulties of identifying the part of the plate in Hortus Elthamensis labelled f. 101 (Dillenius 1732: 103) (Fig. 2A), which they had selected as the lectotype of Ipomoea glaucifolia, but make no mention of the corresponding specimens on which the plate is very clearly based (Figs. 2B, 2C). Likewise in accepting this rejection proposal, the Nomenclature Committee for Vascular Plants makes no mention of the possible existence of a specimen, which might facilitate the correct identification of the plate (Brummitt 2007: 1292).

We have no wish to reverse decisions made about Ipomoea glaucifolia but in lectotypifing Ipomoea glaucifolia with the Dillenius plate, the authors not only ignored the specimens, but did not indicate that the f. 101 (Fig. 2A) actually represents two distinct plants. Both images are in fact almost photographic in their faithfulness to the two original specimens, which are mounted on separate sheets (Figs 2B, 2C). They show the same single and two-flowered inflorescences, the small bracteoles and the distinctive leaf auricles of each specimen. Additionally both sheets are labelled in Dillenius's handwriting with the phrase name as on the plate 'Convolvulus stellatus, arvensis folio glauco' and a reference to 'H. Elth.'. As there is a clear need for a second step lectotypification, we formally designate the painting on the left of f.101 in Hortus Elthamensis (Dillenius 1732: 103) as the lectotype, choosing this in preference to the painting on the right because it corresponds to a more complete specimen (Fig. 2B).

A further striking illustration of the similarity between the plate and the specimen is the case of the plant illustrated under the phrase name 'Convolvulus megalorrhizos, flore amplo purpureo' (Fig. 3A) (Hort. Eltham. 102 t. 86 f. 100). This clearly represents Ipomoea indica (Burm.) Merrill but the illustration shows a most unusual leaf dentation. There are two corresponding sheets in the Sherard herbarium, one labelled with the same phrase name in Dillenius's handwriting (Fig. 3B) and an unlabeled second sheet (Fig. 3C). It is clear that the plate was prepared exclusively from the flowering shoot in the unlabeled sheet. The specimen has been water damaged over the course of time but every detail of the plate can be matched with the surviving parts of the specimen.

The illustration of 'Convolvulus megalorrhizos, flore amplo lacteo, fundo purpureo' (=Ipomoea pandurata (L.) G. Mey.) is also interesting (Hort. Eltham. 101 t. 85 f. 99) (Fig. 4A). It is very clearly based on the specimen shown in Fig. 4B, which shows clearly the three leaf forms found in this specimen, notably the small entire leaf. However, there are three extraneous elements: the fruit, the flower colour and the large separate leaf. The latter may well have been drawn from the second specimen (Fig. 4C) which shows large entire leaves. The flower colour (as also the original phrase name) captures very well the distinct corolla colour of Ipomoea pandurata so it 
seems likely Dillenius had used a living specimen from the Eltham garden unless the colour of the dried specimen was clearer some 285 years ago than it is today.

\section{CONCLUSION}

Our aim in this paper is to draw readers' attention to the importance of the specimens in interpreting the plates that constitute the lectotypes of many Linnaean names. The drawings, especially the coloured versions, often replicate the exact details of the specimens as in the last two cases discussed above. What is true for Convolvulaceae, will often be true for species from other families described in Hortus Elthamensis.

It is obvious that in any case of uncertainty in the interpretation of the many lectotypes of Linnaean species based on the Hortus Elthamensis, recourse should be made to the corresponding specimens in the Dillenian Herbarium (OXF), and the Sherardian Herbarium from which it was extracted. Caution should be exercised in choosing specimens as epitypes as there are examples where there appears to be no correspondence between the specimen and the plate, as in the case of Salvia mexicana L.(Hort. Eltham. 339 t. 254 f. 330). However, there is generally little difficulty in matching a specimen to an illustration, not only by the phrase name in Dillenius's handwriting, which is usually written on the sheet, but also by the resemblance between specimen and plate. In cases where there is more than one specimen associated with a particular plate, comparison of details in the plate with the corresponding specimens will usually enable recognition of which specimen was used in the preparation of the plate. Where required, these specimens can serve as epitypes when the details in the images are insufficient for current taxonomic evaluation. An example of where this has recently been applied is the case of Lantana L., where Sanders (2006) designated epitypes to interpret species lectotypified on images in Hortus Elthamensis which did not show sufficient detail for accurate determination.

\section{AUTHOR CONTRIBUTIONS}

Original study of Ipomoea types by JRIW and RWS. The text was written by JRIW. The plates and specimens were jointly evaluated by JRIW, SKM and SAH. The handwriting and annotations on the sheets were interpreted by SAH. All four authors revised and commented on the manuscript.

\section{ACKNOWLEDGEMENTS}

We are grateful to Andrea Hart (Natural History Museum, London) and to Jochen Müller (Friedrich-Schiller-Universität, Jena) for confirming whether their versions of Hortus Elthamensis were coloured and to James Ritchie at Oxford for help in preparing the figures.

\section{LITERATURE CITED}

Austin, D.F. 1975b. Convolvulaceae. Pp. 157-224 in: Woodson, R.E. \& Schery, R.W. (eds.) Flora of Panama. Annals of the Missouri Botanical Garden 62. http://www.biodiversitylibrary.org/bibliography/702

Brummitt, R.K. 2007. Report of the Nomenclature Committee for Vascular Plants: 59. Taxon 56(4): 1289 - 1296. DOI: 10.2307/25065923 
Clokie, H.N. 1964. An account of the Herbaria of the Department of Botany in the University of Oxford. London: Oxford University Press.

Dillenius J.J. 1732. Hortus Elthamensis, vol 1. London: published by the author. https://www.biodiversitylibrary.org/bibliography/72067\#/

Druce, G.C. \& Vines, S.H. 1907. The Dillenian Herbarium. Oxford: Clarendon Press.

Harris, S.A. 2015. William Sherard; his herbarium and his Pinax. Oxford Plant Systematics 21: 13 -15. http://herbaria.plants.ox.ac.uk/bol/Content/Projects/oxford/ops/ops21

Jarvis, C. 2007. Order out of Chaos. London: Linnaean Society of London and the Natural History Museum.

Klinsmann, E.F. 1856. Clavis Dilleniana ad Hortum Elthamensem. Danzig, L.G.Homann.

Linnaeus, C. 1753. Species Plantarum, 2 vols. Holmiae [Stockholm]: impenis Laurentii Salviae. https://doi.org/10.5962/bhl.title.669

Linnaeus, C. 1762. Species Plantarum, ed. 2, 2 vols. Holmiae [Stockholm]: impenis Laurentii Salviae. https://doi.org/10.5962/bhl.title.11179

Meeuse, A.D.J. 1958 [dated1957]. The South African Convolvulaceae. Bothalia 6: 641-792.

Sanders, R.W. 2006 Taxonomy of Lantana sect. Lantana (Verbenaceae): 1. Correct application of Lantana camara and associated names. Sida, 22: 381: 421.

Schmidt, H. 1965. Der "Hortus Elthamensis" aus der Bibliothek CARL VON LINNÉS. Repert. Spec. Nov. Regni. Veg. 70: 69-108

Shinners, L.H. 1965. Untypification of Ipomoea nil (L.) Roth. Taxon 14: 231-234. DOI: $10.2307 / 1216296$

Staples, G.W., Austin, D.F. \& McDonald, J.A. 2006. Proposal to reject the name Ipomoea glaucifolia (Convolvulaceae). Taxon 55: 535-536. DOI: 10.2307/25065609

Staples, G.W. \& Jarvis, C. 2006. Typification of Linnaean Plant Names in Convolvulaceae. Taxon 55: 1019-1024. DOI: 10.2307/25065700

Stearn, W.T. 1957. Introduction. Pp. 1 - 176 in Linnaeus, C. Species Plantarum, A Facsimile of the first edition. London: The Ray Society.

Verdcourt, B. 1957. The names of the Morning Glories cultivated and naturalised in East Africa. Taxon 6: 231-233. DOI: 10.2307/1217468

Wood, J.R.I., Williams, B.R.M., Mitchell, T.C., Carine, M.A., Harris, D.J. \& Scotland, R.W. 2015a. A Foundation Monograph of Convolvulus (Convolvulaceae). Phytokeys 51: 1 282. DOI: $10.3897 /$ phytokeys.51.7104

Wood, J.R.I., Carine, M.A., Harris, D.J., Wilkin, P., Williams, B.R.M. \& Scotland, R.W. 2015b. Ipomoea (Convolvulaceae) in Bolivia. Kew Bulletin 70(31): 1 - 124. DOI: $10.1007 / \mathrm{S} 12225-015-9592-7$ 
